\title{
The effects of pentoxifylline into the kidneys of rats in a model of unilateral hindlimb ischemia/reperfusion injury ${ }^{1}$
}

\author{
Efeitos da pentoxifilina no rim de ratos em um modelo de lesão de isquemia e \\ reperfusão do membro posterior
}

\author{
Roberto Teruya I, Djalma José Fagundes", Celina Tizuko Fujiyama Oshima ${ }^{\mathrm{III}}$, José Lacerda Brasileiro ${ }^{\mathrm{I}}$, Guido \\ Marks $^{I}$, Celso Massachi Ynouye ${ }^{\mathrm{IV}}$, Manuel Jesus Simões ${ }^{\mathrm{V}}$ \\ I Master, Affiliate Professor, Surgery Clinic Department, Federal University of Mato Grosso do Sul, (UFMS), Brazil. \\ II Master, PhD, Associate Professor, Division of Operative Technique and Experimental Surgery, Department of Surgery, UNIFESP, São \\ Paulo, Brazil. \\ III BioSci, Master, PhD, Affiliate Professor, Molecular Pathology Division, Department of Pathology, UNIFESP, São Paulo, Brazil. \\ IV Master, PhD, Associate Professor, Surgery Clinic Department, Federal University of Mato Grosso do Sul, (UFMS), Brazil.

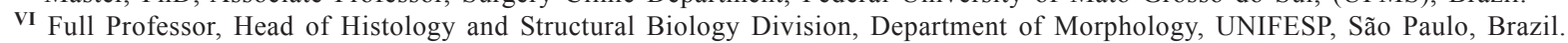

\begin{abstract}
Purpose: To study the role of pentoxifylline (PTX) on remote kidney injury caused by muscle ischemia of left hindlimb of rats. Methods: After xylazine and ketamine anesthesia, the left hindlimb of rats ( $\mathrm{n}=66)$ were submitted to 6 hours ischemia (clamping the left common iliac artery). Three groups were used: sham group ( $\mathrm{SG}, \mathrm{n}=6)$, early group (EG, $n=30)$ with reperfusion after 4 hours and late group $(L G, n=30)$ with reperfusion after 24 hours. The saline solution $(E G 1, n=10$ and LG1, $\mathrm{n}=10)$ or PTX (40mg. $\left.\mathrm{Kg}^{-1}\right)$ was administered in the reperfusion beginning (EG2, n=10/LG2, $\mathrm{n}=10$ ) or divided in two doses in the ischemia beginning and reperfusion beginning ( $E G 3, n=10 / L G 3, n=10)$. The plasmatic creatinokinase, urea, creatinine, sodium and potassium values were measure and histological samples from left kidney were prepared and H\&E stained for scored cellular necrosis and degeneration of kidney tubules and thickness glomerulus determination. The apoptosis index was determined by immunohistochemical expression of the caspase-3. The tests of Mann-Whitney and Kruskal-Wallis $(\mathrm{p} \leq 0.05)$ were applied. Results: The urea $\left(90.5 \pm 30.96 \mathrm{mg}^{\mathrm{dL}} \mathrm{dL}^{-1}\right)$, creatinine $(2.28 \pm$ $\left.0.54 \mathrm{mg} . \mathrm{dL}^{-1}\right)$, potassium $\left(16 \pm 3.66 \mathrm{mmol}_{\mathrm{dL}} \mathrm{dL}^{-1}\right)$ and mesangium thickness $(0.97 \pm 0.42 \mu \mathrm{m})$ values were significantly higher in group LG3. There was no significantly difference of caspase 3 expression between EG2 (16.35 $\pm 1.65 \%)$ and LG3 $(15.57 \pm 2.54 \%)$, and both were significantly worse than SG $(9.8 \pm 1.98 \%)$. Conclusions: The PTX has some protecting effect on remote kidney injury due to hindlimb ischemia/reperfusion injury only in the early phase of reperfusion.
\end{abstract}

Key words: Ischemia. Muscle, Skeletal. Kidney. Pentoxifylline. Caspase 3. Rats.

\section{RESUMO}

Objetivo: Estudar o papel da pentoxifilina (PTX) nas lesões à distância no rim causadas pela isquemia no membro posterior esquerdo de ratos. Métodos: Sob anestesia com xilazina e quetamina, o membro posterior de ratos ( $\mathrm{n}=66$ ) foi submetido a 6 horas de isquemia pelo clampeamento da artéria ilíaca comum esquerda. Foram estudados três grupos: grupo simulado $(\mathrm{SG}, \mathrm{n}=6)$, grupo precoce $(\mathrm{EG}, \mathrm{n}=30)$ após quatro horas de reperfusão e grupo tardio ( $\mathrm{LG}, \mathrm{n}=30)$ após 24 de reperfusão. A solução salina (EG1, n=10 e LG1, n=10) ou a PTX (40mg. Kg $\left.{ }^{-1}\right)$ foram administradas no início da reperfusão(EG2, n=10/LG2, $\mathrm{n}=10$ ) ou divididas em duas aplicações no início da isquemia e no início da reperfusão (EG3, n=10/LG3, n=10). Foram medidos os valores plasmáticos da creatinofosfoquinase, uréia, creatinina, sódio e potássio. Amostras do rim esquerdo foram preparadas e coradas em HE para realizar o escore de necrose de células tubulares renais ou presença de obstrução tubular renal na área do córtex renal e da presença do espessamento do mesângio glomerular. O índice de apoptose foi determinado pela expressão imunoistoquímica da caspase-3. Foram aplicados os testes de Mann-Whitney e KruskalWallis $(\mathrm{p} \leq 0.05)$. Resultados: a dosagem de uréia $\left(90,5 \pm 30,96 \mathrm{mg}_{\mathrm{dL}} \mathrm{dL}^{-1}\right)$, creatinina $\left(2,28 \pm 0,54 \mathrm{mg} \cdot \mathrm{dL}^{-1}\right)$, potássio $(16 \pm 3,66$ mmol.dL $\left.{ }^{-1}\right)$ e a espessura do mesângio $(0,97 \pm 0,42 \mu \mathrm{m})$ foram significantemente maiores nos animais do grupo LG3. Não houve diferença significante na expressão da caspase-3 entre os grupos EG2 (16,35 $\pm 1,65 \%)$ e LG3 (15,57 $\pm 2,54 \%)$ e ambos foram significantemente piores que o grupo SG $(9,8 \pm 1,98 \%)$. Conclusão: A PTX oferece algum efeito protetor nas lesões à distância nos rins de animais submetidos à lesão de isquemia e reperfusão de membro posterior, no período de até quatro horas após a reperfusão.

Descritores: Isquemia. Músculo Esquelético. Rim. Pentoxifilina. Caspase 3. Ratos.

1. Research performed at Surgery and Experimentation Post-Graduate Program, Operative Technique and Experimental Surgery Division, Department of Surgery, Federal University of São Paulo (UNIFESP), Brazil. 


\section{Introduction}

Reperfusion of the acutely ischemic limb may, paradoxically, lead to systemic complications that account for significant morbidity and mortality ${ }^{1}$. Skeletal muscle ischemia-reperfusion is associated with a systemic inflammatory response and determines the effect on remote organs (lung, liver, and kidney) structure and function ${ }^{1,2}$. It is well known that interactions between the blood elements and the vascular endothelium are responsible for the reperfusion injury: endothelial injury with swelling and lysis due to loss of ionic and osmotic gradients, loss of vasoregulatory control, diminished of the endotheliumderived vasodilator nitric oxide, polymorph nuclear leukocytes (PMN) activation and subsequent release of lytic enzymes leading to tissue damage ${ }^{1,2}$.

The development of remote organ dysfunction was observed only following reperfusion, which implies that humoral and/or cellular mediators produced locally in the limb were responsible for mediating remote organ injury ${ }^{3,4}$. The failure to identify histological evidence of injury in the kidney may indicate that injury in this organ was not severe enough to cause structural damage. Since functional derangement normally precedes evidence of structural organ injury, the experimental ischemia period must be long enough to allow for the structural changes to develop. Although histological evidence of injury was demonstrated only in the lung, the biochemical evidence of simultaneous hepatic and renal dysfunction indicates that multiple organ dysfunctions following hindlimb ischemia reperfusion occur as a central systemic event rather than sequential failure of individual organs ${ }^{4,5,6}$.

Multiple pharmacological agents could potentially limit reperfusion injury, including substances that target free radicals, limit initiation of the inflammatory response, or serve as substrate for compounds that preserve endothelial function ${ }^{7}$. Pentoxifylline (PTX) is a methylxanthine derivative with multiple hemorheologic properties. PTX through effects of increasing intracellular cyclic AMP on red blood cells improve the oxygen delivery to ischemic tissues and also increases the AMP cyclic on PMN and decreased oxygen free radical production ${ }^{7-11}$. In addition, PTX limited the inflammatory response with reduction in cellular activation, phagocytosis and endothelium adhesion. There are evidences that PTX also reduces the nitric oxide destruction ${ }^{10}$.

The purpose of this study was to determine whether hindlimb ischemia-reperfusion is associated with the effect on remote organ structure and function, like the kidney, in a rat model and, secondly, to determine the role of PTX modulation on this remote kidney damage.

\section{Methods}

The experimental protocol was approved by the Ethics Committee of the Federal University of São Paulo Escola Paulista de Medicina (UNIFESP - EPM), São Paulo, Brazil, ratified and developed at Federal University of Mato Grosso do Sul (UFMS), Campo Grande, MS, Brazil. All the procedures followed, rigorously, the existent regulations about animal experimentation.
Sixty-six male Wistar rats, four months aged, weighing between 300-350g were acclimated to laboratory conditions for 7 days and fed a standard rat chow and water ad libitum. All the surgical procedures and ischemia periods were done under general anesthesia, using intraperitonial ketamine (50mg. $\left.\mathrm{Kg}^{-1}\right)$, xylazine (20mg. $\mathrm{Kg}^{-1}$ ) and spontaneous respiration. All procedures were done in a heating environment. The analgesic nalbuphine hydrochloride $\left(\right.$ Nubain $\left.^{\mathrm{TM}}\right)$ was used in a subcutaneous via $\left(2 \mathrm{mg} \cdot \mathrm{Kg}^{-1}\right)$ during four or twenty-four observation time.

At first, all animals were submitted to laparotomy with exposure of the infrarenal abdominal aorta and the bilateral iliac arteries. The complete ischemia was induced by a vascular clamping of the left common iliac artery. The ischemia was verified by the absence of distal arteries pulses and by absence of Doppler signals (Medison- Sonoace $9900^{\mathrm{TM}}$ - Linear transductor 5-12MHz). After six hours of ischemia the clamp was removed, and reperfusion was documented by return of Doppler signals in the distal arteries. The abdominal wound was closed by total continuous nylon 4.0 suture and the animals return to the heating cages for four or twenty-four hours of reperfusion time observation. The $3 \mathrm{~mL}$ of PTX (Trental $^{\mathrm{TM}}$ - Sanofi Aventis) dose (40mg. $\mathrm{Kg}^{-1}$ ) was administered by intraperitoneal via.

The artery clamping was avoid in the animals of sham group $(\mathrm{SG}-\mathrm{n}=6)$ and three were sacrificed at four and another three at twenty-four hours of reperfusion. The animals of reperfusion of four hours (early phase) (EG $\mathrm{n}=30)$ and twenty four hours (late phase) $(\mathrm{LG}-\mathrm{n}=30)$ were divided in group with no PTX (EG1-n=10 and LG1-n=10), group with PTX immediately before the reperfusion time (EG2-n=10 and LG2-n=10) and group with PTX immediately after the ischemia and immediately before the reperfusion time (EG3-n=10) and LG3-n=10).

At end of reperfusion time the surgical wound was reopened and the left nefrectomy was performed and a venous blood was colleted from left cardiac camera. The animals were euthanized by high-dose of anesthetics until cardiac arrest.

The blood samples were analyzed by Automatic DADE Analyzer ${ }^{\mathrm{TM}}$ (Behring Dimension AR) to determine the biochemical plasmatic measures of creatinokinase (CK), urea, creatinine, sodium and potassium.

Samples of the left kidney was immersed in a volume of $10 \%$ formalin solution ten times over the kidney volume, embedded in paraffin wax and $4 \mu \mathrm{m}$ sections were cut and stained with hematoxilin and eosin. Histological evaluation was undertaken by an independent pathologist who had no knowledge of the experimental groups from which the specimens were derived. The macroscopic assessment was performed using the follow grading scoring: 0 (no changes), 1 (mild), 2 (moderate) and 3 (severe). The abnormalities detected in 20 random sites in every animal plate were subjectively scored and compared with the controls. The evaluated parameters were mesangio thickness, renal tubules degeneration and necrosis. The tissue injury was evaluated by the sum of parameters (minimum $=0$ to maximum $=21)$. The sections were carefully examined microscopically and the best observed areas were selected 
for morphometric studies. The images were captured in a high-resolution Samsung ${ }^{\circledR}$ camera coupled to a light Nikon E200 ${ }^{\circledR}$ microscope by the AxioVision-Rel ${ }^{\circledR}$ software (Zeiss). In 20 selected sites the mesangio thickness was measured $(\mu \mathrm{m})$ from the ratio of glomerulus and the Bowman capsule. Immunohistochemistry for caspase-3 (rabbit polyclonal antibody - Sigma Chemical Corporation, P- 7886, Saint Louis MO. USA - Cuello, A.C., Immunohistochemistry II, Wiley Press, NY - 1993) was performed using a combination avitinbiotin-peroxidase method and microwave antigen retrieval on formalin-fixed paraffin-embedded tissues. After deparaffinization, sections were treated with $10 \%$ hydrogen peroxidase in filtered water to block endogenous peroxidase activity. To retrieve the antigen, slides were boiled with 10 $\mathrm{mmol} / \mathrm{l}$ citrate buffer $(\mathrm{pH} 6.8)$ for $10 \mathrm{~min}$. After pre incubation with for $20 \mathrm{~min}$, sections were incubated with the primary antibody for $1 \mathrm{~h}$ at room temperature, followed sequentially by biotinylated goat 1:300 (Vector Corporation, Burlingame, California, USA). We used Harris' hematoxylin, as the chromagen, and hematoxylin for nuclear counterstain. The slides were evaluated in a blinded fashion by the same investigator. The images were captured through a high resolution camera by the Imagelab software ${ }^{\circledR}$ and the analysis was conducted in a Nikon E $200^{\circledR}$ optic microscope. The software used was the Imagelab ${ }^{\circledR}$ that calculated the ratio of brown color tissue/no brown color tissue. Apoptotic cells in the renal cortex were counted in ten slices of ten separate regions.

Statistics were performed on SPSS software (SPSS ${ }^{\text {TM }}$ Inc. Chicago, IL, USA). The significance of the differences in histological scores and in thiness measurements were made by Mann Whitney and the Kruskall Wallis. A $P$ value $\leq 0.05$ was considered to be statistically significant.

\section{Results}

The comparison of CK (values in U.L $\mathrm{L}^{-1}$ ) from the sham group $(751.00 \pm 130.79)$ with the group EG1 (3332.30 1384.39$)$ and LG1 (2215.00 \pm 1823.14$)$ shown that the ischemia led to damage of skeletal muscle, but the PTX do not protected the muscle after the reperfusion (Figure 1). In fact, it was evident on early phase with PTX only in the ischemia EG2 $(3143.60 \pm 1604.57)$ or both ischemia and reperfusion time
EG3 (2010.70 \pm 705.43$)$ and in the late phase LG2 (2074.10 \pm 1004.32$)$ or LG3 (2451.20 \pm 1831.87$)$.

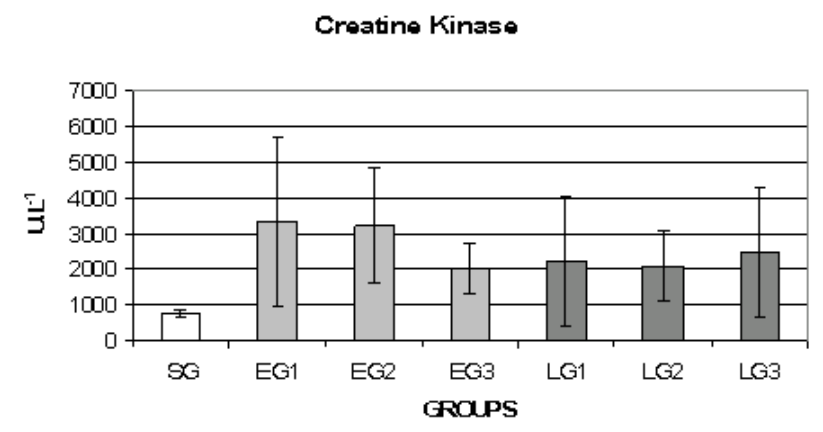

FIGURE 1 - CK plasmatic concentration (mean \pm sd) in sham group (SG), I/R 4 hours group (EG) and I/R 24 hours group (LG) without PTX (1), with PTX at initial ischemia time (2) and PTX at initial of ischemia and initial reperfusion time (3). Values in U.L $L^{-1}$ (mean \pm sd)

There was no significant increase of plasmatic urea values in the comparison of sham group (53.23 \pm 4.68$)$ with EG1 (65.30 \pm 22.25$)$ and LG1 (58.56 \pm 13.23$)$. In the early phase the PTX do not diminished the plasmatic urea level in EG2 $(68.40 \pm 20.19)$ and EG3 (57.10 \pm 9.34$)$ groups. In the late phase LG2 $(62.30 \pm 19.72)$ and LG3 $(90.50 \pm 30.96)$ the urea plasmatic level was significantly greater than the sham and the LG1. The fact can mean that PTX do not protected the renal function and instead probably impaired them.

The same profile occurred with the plasmatic values of creatinina. There was no significant increase of urea values in the comparison of sham group $(0.73 \pm 0.14)$ with EG1 (0.96 \pm 0.42$)$ and LG1 (1.22 \pm 0.25$)$. In the early phase the PTX do not diminished the plasmatic creatinine level in EG2 (1.06 $\pm .0 .19)$ and EG3 (0.79 \pm 0.09$)$ groups. In the late phase LG2 $(0.97 \pm 0.43)$ and LG3 $(2.28 \pm 0.54)$ the creatinine plasmatic level was significantly greater than the sham and the LG1 (Figure2)
URELA

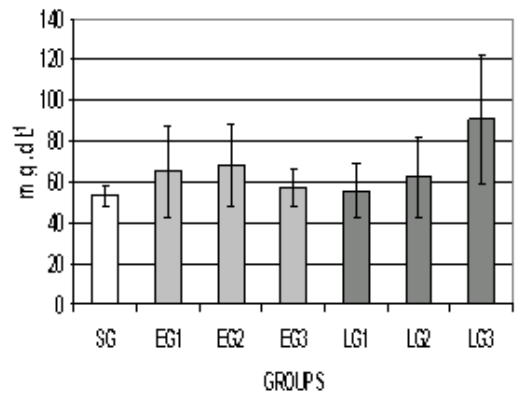

CPEATINE

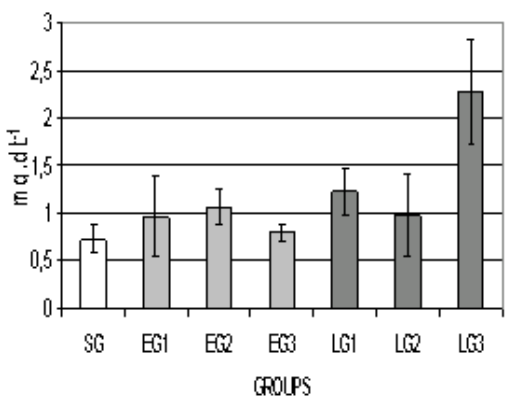

FIGURE 2 - Urea and creatinine plasmatic concentration (mean \pm sd) in sham group (SG), I/R 4 hours group (EG) and I/R 24 hours group (LG), without PTX (1), with PTX at initial ischemia time (2) and PTX at initial of ischemia and initial reperfusion time (3). Values in mmol.dl $^{-1}($ mean \pm sd $)$ 
The plasmatic concentration of sodium on the EG1 (151.60 \pm 7.00$)$ was significantly greater than the sham group $(141.17 \pm 2.23)$. The PTX administration does not had any influence and the level of plasmatic sodium concentration

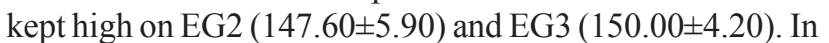
the late phase the sodium concentration of LG2 (155.20 \pm 6.60$)$ and LG3 (160.00 \pm 3.23$)$ was significantly greater than those of sham group early phase groups.

The similar profile occurred with the plasmatic values of potassium. The plasmatic concentration of potassium on the EG1 $(10.1 \pm 2.05)$ was significantly greater than the sham group (5.08 \pm 0.66$)$. The PTX administration does not had any influence and the level of plasmatic potassium concentration kept high on EG2 (12.2 \pm 3.38$)$ and EG3 $(6.0 \pm 0.77)$. In the late phase the potassium concentration of
LG2 (10.3 \pm 5.12$)$ and LG3 (16.0 \pm 3.66$)$ was significantly higher than those of sham group early phase groups (Figure 3 ).

The enlargement of glomerulus area occurred meanly by liquid sequestration (edema) and there was no significantly differences with the EG1 $(0.74 \pm 0.07)$ and EG2 $(0.64 \pm 0.21)$, but occurred a significantly difference with the EG3 $(0.88 \pm 0.07)$. The edema become more evident in the late phase in the groups LG1 $(0.59 \pm 0.07)$, LG2 $(0.85 \pm 0.33)$ and LG3 (0.97 \pm 0.42$)$.

The deposit of amorphous substances or necrotic cells on the kidney tubules and morphological evidences of cell necrosis was significantly higher in EG2 (1.15 \pm 0.07$)$ and EG3 (1.20 \pm 0.21$)$ in comparison with EG1 $(0.84 \pm 0.14)$. In the late phase there was no significant differences among LG1

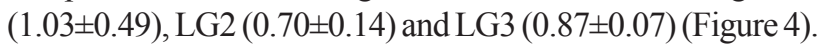

SOOIN

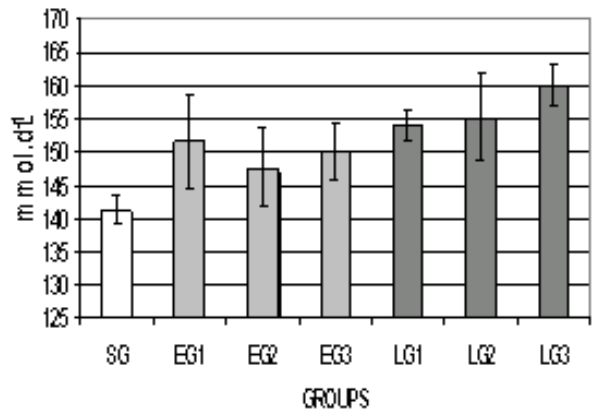

POTASSNM

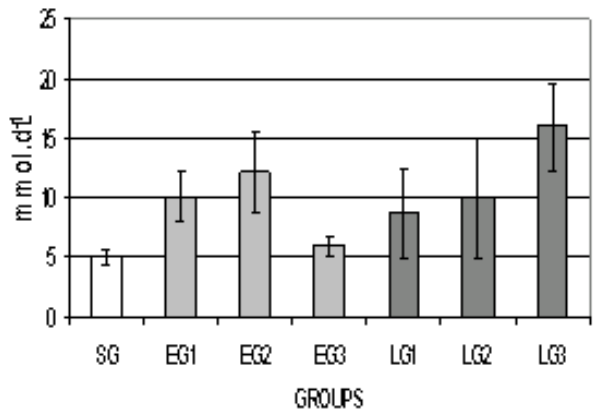

FIGURE 3 - Sodium and potassium plasmatic concentration (mean \pm sd) in sham group (SG), I/R 4 hours group (EG) and I/R 24 hours group (LG), without PTX (1), with PTX at initial ischemia time (2) and PTX at initial of ischemia and initial reperfusion time (3). Values in mmol.dl $^{-1}$ (mean \pm sd)

MESANGUNITCKNESS

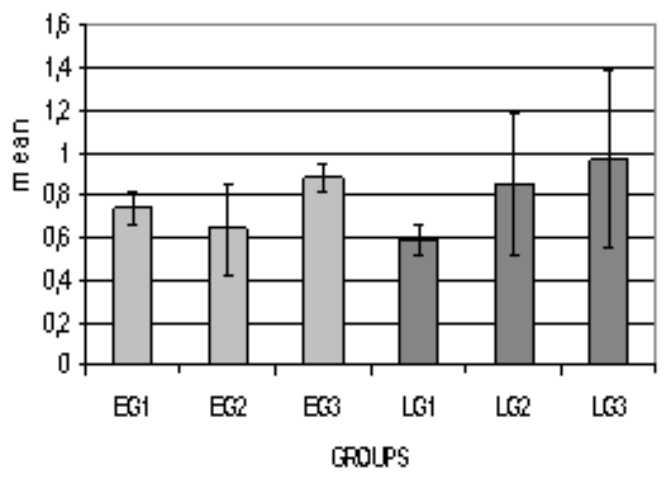

CEШLARNECROSSORDECENERATION ONCORTCALAREA

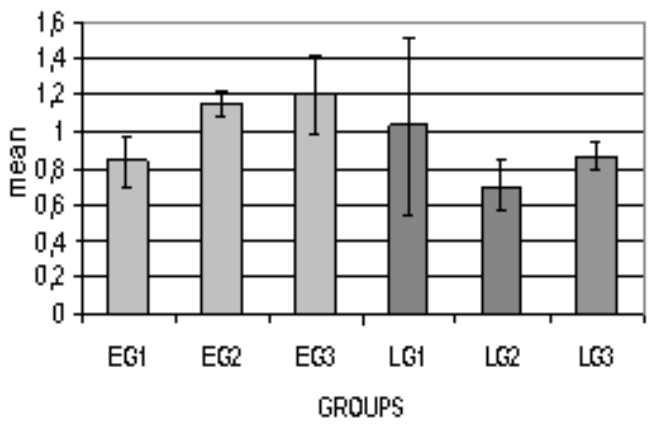

FIGURE 4 - Mesangio thickness $\left[\mu \mathrm{m}^{2}(\right.$ mean $\left.\pm \mathrm{sd})\right]$ and percentage of damaged renal tubules (mean \pm sd) in sham group (SG), I/R 4 hours group (EG) and I/R 24 hours group (LG), without PTX (1), with PTX at initial ischemia time (2) and PTX at initial of ischemia and initial reperfusion time (3) 
A significantly differences occurred in the apoptosis expressed by caspase-3 in the groups EG1 (11.86 \pm 2.40$)$, EG2 (14.16 \pm 4.55$)$ and EG3 (10.38 \pm 1.54$)$ in comparison with SG (9.8 \pm 1.98$)$. The PTX increased the caspase-3 expression in the late phase too, as shown by the results in LG1 (14.19 \pm 3.72), LG2 (16.35 \pm 1.65$)$, and LG3 (15.57 \pm 2.54 ) (Figure 5).

CASPASE-3 EXPRESSION

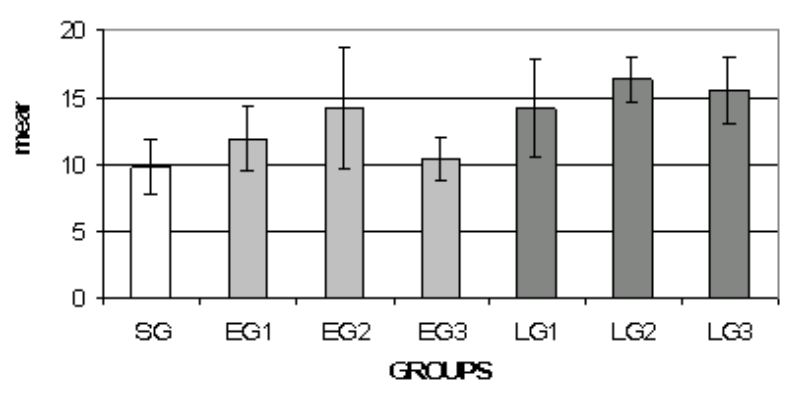

FIGURE 5 - Caspase- 3 expression (mean \pm sd) in sham group (SG), I/R 4 hours group (EG) and I/R 24 hours group (LG), without PTX (1), with PTX at initial ischemia time (2) and PTX at initial of ischemia and initial reperfusion time (3)

\section{Discussion}

Morbidity and mortality following reperfusion of the acutely ischemic limb may be a manifestation of multiple organ dysfunction caused by a systemic inflammatory response triggered by reperfusion of the ischemic extremities.

The findings in this study indicate that reperfusion of the ischemic limb leads, within four or twenty-four hours of reperfusion, to a systemic response as demonstrated by the functional and morphological impairment of the kidney.

Magdi et $\mathrm{al}^{2}$ related that the restoration of blood flow to an acutely ischemic lower limb in rats may, paradoxically, result in systemic complications and unexpected mortality. There was a significant increase in plasma concentrations of urea, creatinine, aspartate transaminase, alanine transaminase, and lactic dehydrogenase in reperfused animals compared with controls. Plasma concentrations of tumor necrosis factoralpha (TNF-a) and interleukin-6 increased progressively and significantly in animals subjected to bilateral hind limb ischemia followed by 1 hour of reperfusion.

In our experimental model of unilateral hindlimb ischemia was associated to significant increase of plasmatic sodium and potassium (Figure 3 ) at four $(\mathrm{p}<.0159)$ or twentyfour hours $(\mathrm{p}<0.42)$ and the mild increase (Figure 2$)$ of urea $(p<0.0399)$ and creatinine $(p<0.0382)$ shown the function renal impairment caused by the skeletal muscle I/R injury. The mesangial enlargement and the tubular cells necrosis (Graphic 4) were evidences of the remote I/R renal injury.

Gradl et $\mathrm{al}^{4}$ reported that remote organ failure is attributed to the systemic action of locally released mediators; it is so far unclear to what extent a direct cell injury and the consequences of ischemia or a secondary injury due to locally released mediators contribute to the manifestation of tissue damage at the primary site of trauma. Rats that underwent traumatized muscle presented with apoptotic cell death, as given by in vivo fluorescence microscopy, caspase-3 protein cleavage. They suggested that may prompt future efforts in the therapy of ischemia/ reperfusion injury to focus not only on antimediator strategies, but to add regimens targeting perfusion failure and tissue apoptosis.

The caspase-3 cleavage expression of our sham group was significantly lesser than that of group after four hours of reperfusion [EG1 (0.0378)] or twenty-four hours [LG1 (0.0398)]. The hindlimb I/R injury led to a remote increase of apoptosis in renal parenchyma.

Although a diversity of mechanisms exist by which the kidney can be damaged during muscle ischemia, inflammatory response and the apoptosis are believed to be primary contributors to renal insult. In addition, the high metabolic demands of active tubular reabsorption and the oxygen diffusion shunt characteristic of renal circulation make the kidney particularly vulnerable to ischemic injury. Although numerous pharmacologic interventions to prevent or treat acute renal injury have shown promise in animal models no one is safe and effective enough to be used in large scale ${ }^{12-14}$.

The beneficial effects of post-insult administration of PTX were related as an agent experimentally studied in various ischemic diseases, including in models of renal impairment due to remote muscle ischemia/reperfusion injury 14-17.

The current range dose of PTX related is from $20 \mathrm{mg} . \mathrm{Kg}^{-1}$ to $45 \mathrm{mg} . \mathrm{Kg}^{-1}$ i.p. using rats or rabbits models. On the other hand, there were various designs of administration time. The PTX may be used in chronic or acute essays. In models of acute $\mathrm{I} / \mathrm{R}$ injury the administration were often done in the reperfusion time. Since these events occur in flowing blood, PTX needs to be present in this milieu to exert its effects ${ }^{1}$.

In our model, after four hours of reperfusion (early group), the PTX (40mg. $\mathrm{Kg}^{-1}$ i.p.) administrated in the beginning of ischemia do not reduced significantly the plasmatic level of urea, creatinine, sodium, potassium, neither the caspase-3 expression. On the other hand, when PTX was administrated in the beginning of ischemia (half dose) and beginning of reperfusion (second half dose) occurred a significantly reduction in the plasmatic levels of creatinine $(\mathrm{p}<0.0374)$ and potassium $(\mathrm{p}<0.0405)$ and a mild tendency of reduction in the sodium $(\mathrm{p}<0.0523)$ and urea $(\mathrm{p}<0.0589)$. Furthermore, the caspase expression showed significantly decrease when administrated in the beginning of ischemia and beginning of reperfusion. Our results reinforced that is thought about the presence of PTX on blood circulation to lead the better effects. 
Nevertheless, after twenty-four hours of reperfusion the plasmatic levels of urea, creatinine, sodium and potassium showed no significantly difference with the group without PTX and PTX administrated in the beginning of ischemia. The same profile occurred with the caspase-3 expression. The PTX in the beginning of ischemia and beginning of reperfusion was associated to a significantly increase in the plasmatic of creatinine $(p<0.0359)$, while the urea $(\mathrm{p}<0.0589)$, sodium $(\mathrm{p}<0.0532)$ and potassium $(\mathrm{p}<0.567)$ showed a discreet increase. The caspase- 3 expression showed no differences with others groups. Our results implied that PTX was associated to worse results when used in the late time. There were no others similar reports in the biomedical literature and further investigation should be done to clarify this point.

The edema and tubular necrosis (Figure 4) had the same profile in the early and late phases with no significantly differences with the period of PTX administration. The PTX do not protected the kidney from necrosis and edema due to the remote muscle $\mathrm{I} / \mathrm{R}$ injury.

These unexpected results in the late period probably should be associated to some bias occurred in the hydro-electrolytic balance, in the divided PTX doses or on the dose concentration. Another design will be performed focused in the effects of PTX in the late time reperfusion.

Our data support the favorable role of PTX to protect the kidney from remote skeletal muscle $1 / \mathrm{R}$ injury, when applied in the reperfusion time and until four hours after reperfusion. The protection after twenty-four hours should be object of further studies because conflicting results with the rational use of PTX and the others result reported in the biomedical revue.

\section{References}

1. Coe DA, Freischlag JA, Johnson D, Mudaliar JH, Kosciesza SA, Traul DK, Chiang PC, Cambria RA, Seabrook GR, Towne JB. Pentoxifylline prevents endothelial damage due to ischemia and reperfusion injury. J Surg Res. 1997;67(1):21-5.

2. Yassin MM, Harkin DW, Barros D’Sa AA, Halliday MI, Rowlands BJ. Lower limb ischemia-reperfusion injury triggers a systemic inflammatory. World J Surg. 2002;26(1):115-21.

3. Emrecan B, Tulukoglu E, Bozok S, Kestelli M, Onem G, Küpelioglu A, Yagdi S, Gürbüz. A Effects of lloprost and pentoxifylline on renal ischemia-reperfusion in rabbit model. Eur J Med Res. 2006;11(7):295-9.

4. Gradl G, Gaida S, Finke B, Lindenblatt N, Gierer P, Menger MD, Mittlmeier T, Vollmar B. Supernatant of traumatized muscle induces inflammation and pain, but not microcirculatory perfusion failure and apoptotic cell death. Shock. 2005;24(3):219-25.
5. Wang WZ, Stepheson LL, Fang XH, Khiabani KT, Zamboni WA. Ischemic preconditioning-induced microvascular protection at a distance. J Reconstr Microsurg. 2004;20(2):175-81.

6. Olguner C, Koca U, Kar A, Karci A, Islekel H, Canyilmaz M, Mavioglu O, Kizildag S, Unlü G, Elar Z. Ischemic preconditioning attenuates the lipid peroxidation and remote lung injury in the rat model of unilateral lower limb ischemia reperfusion. Acta Anaesthesiol Scand. 2006;50(2):150-5.

7. Stafford-Smith M. Evidence-based renal protection in cardiac surgery. Semin Cardiothorac Vasc Anesth. 2005;9(1):65-76.

8. Vadiel K, Brunner LJ, Luke DR. Effects of pentoxyfilline in experimental acute renal failure. Kidney Int. 1989;36(3):46670.

9. Emrecan B, Tulukoglu E, Bozok S, Kestelli M, Onem G, Kupelioglu A, Yagdi S, Gurbuz A. Effects of lloprost and pentoxyfilline on renal ischemia-reperfusion in rabbit model. Eur J Med Res. 2006;11(7):295-9.

10. Dávila-Esqueda ME, Martinez-Morales F. Pentoxifylline diminishes the oxydative damage renal tissue induced by streptozotocin in the rat. Exp Diabesity Res. 2004;5(4):245-51.

11. Gunduz Z, Canoz O, Per H, Dusunsel R, Poyrazoglu MH, Tez C, Saraymen R The effects of pentoxifylline on diabetic renal changes in streptozotocin-induced diabetes mellitus. Ren Fail. 2004;26(6):597-605.

12. Lin SL, Chen YM, Chiang WC, Tsai TJ, Chen WY Pentoxifylline: a potential therapy for chronic kidney disease. Nephrology. 2004;9(4):198-204.

13. DiPetrillo K, Gesek FA. Pentoxifylline ameliorates renal tumor necrosis factor expression, sodium retention, and renal hypertrophy in diabetic rats. Am J Nephrol. 2004;24(3):352-9.

14. Aslan A, Karagüzel G, Güngör F, Izgüt-Uysal N, Aydin F, Melikoglu M. The effects of pentoxifylline on renal function and free radical production in unilateral ureteral obstruction. Urol Res. 2003;31(5):317-22.

15. Yagmurlu A, Boleken ME, Ertoy D, Ozsan M, Gokcora $\mathrm{IH}$, Dindar H. Preventive effect of pentoxifylline on renal 
scarring in rat model of pyelonephritis. Urology. 2003;61(5):1037-41.

16. Savic V, Vlahovic P, Djordjevic V, Mitic-Zlatkovic M, Avramovic V, Stefanovic V. Nephroprotective effects of pentoxifylline in experimental myoglobinuric acute renal failure. Pathol Biol. (Paris) 2002;50(10):599-607.

\section{Correspondence:}

Roberto Teruya

Rua Aluízio de Azevedo 1330, 204 B1 F

79004-050 Campo Grande - MS Brazil

Phone: (55 67)3341-3669

wakateteruya@uol.com.br
Conflict of interest: none

Financial source: none

Received: August 21, 2007

Review: October 25, 2007

Accepted: November 20, 2007

\section{How to cite this article}

Teruya R, Fagundes DJ, Oshima CTF, Brasileiro JL, Marks G, Ynouye CM, Simões MJ. The effects of pentoxifylline into the kidneys of rats in a model of unilateral hindlimb ischemia/reperfusion injury. Acta Cir Bras. [serial on the Internet] 2008 Jan-Feb;23(1). Available from URL: http://www.scielo.br/acb 